$\mathcal{E}_{\text {Iransport Forum }}^{\text {International }}$

The Governance

and Regulation of Ports

The Case of Italy

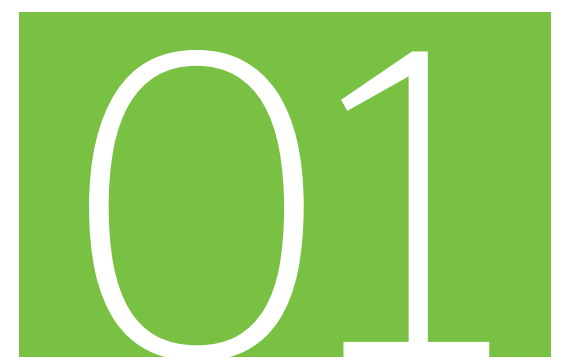

Discussion Paper 2015•01

Claudio Ferrari, Alessio Tei

University of Genova, Italy

Olaf Merk

International Transport Forum, Paris, France 


\title{
The Governance and Regulation of Ports
}

\author{
The Case of Italy
}

Discussion Paper No. 2015-01

Claudio FERRARI, Alessio TEI

University of Genova, Italy

Olaf MERK

International Transport Forum

January 2015 


\section{THE INTERNATIONAL TRANSPORT FORUM}

The International Transport Forum at the OECD is an intergovernmental organisation with 54 member countries. It acts as a strategic think-tank, with the objective of helping shape the transport policy agenda on a global level and ensuring that it contributes to economic growth, environmental protection, social inclusion and the preservation of human life and well-being. The International Transport Forum organises an annual summit of Ministers along with leading representatives from industry, civil society and academia.

The International Transport Forum was created under a Declaration issued by the Council of Ministers of the ECMT (European Conference of Ministers of Transport) at its Ministerial Session in May 2006 under the legal authority of the Protocol of the ECMT, signed in Brussels on 17 October 1953, and legal instruments of the OECD.

The Members of the Forum are: Albania, Armenia, Australia, Austria, Azerbaijan, Belarus, Belgium, Bosnia and Herzegovina, Bulgaria, Canada, Chile, People's Republic of China, Croatia, Czech Republic, Denmark, Estonia, Finland, France, Former Yugoslav Republic of Macedonia, Georgia, Germany, Greece, Hungary, Iceland, India, Ireland, Italy, Japan, Korea, Latvia, Liechtenstein, Lithuania, Luxembourg, Malta, Mexico, Republic of Moldova, Montenegro, Netherlands, New Zealand, Norway, Poland, Portugal, Romania, Russian Federation, Serbia, Slovak Republic, Slovenia, Spain, Sweden, Switzerland, Turkey, Ukraine, United Kingdom and United States.

The International Transport Forum's Research Centre gathers statistics and conducts co-operative research programmes addressing all modes of transport. Its findings are widely disseminated and support policymaking in Member countries as well as contributing to the annual summit.

\section{Discussion Papers}

The International Transport Forum's Discussion Paper Series makes economic research, commissioned or carried out at its Research Centre, available to researchers and practitioners. The aim is to contribute to the understanding of the transport sector and to provide inputs to transport policy design.

ITF Discussion Papers should not be reported as representing the official views of the ITF or of its member countries. The opinions expressed and arguments employed are those of the authors.

Discussion Papers describe preliminary results or research in progress by the author(s) and are published to stimulate discussion on a broad range of issues on which the ITF works. Comments on Discussion Papers are welcomed, and may be sent to: International Transport Forum/OECD, 2 rue André-Pascal, 75775 Paris Cedex 16, France.

For further information on the Discussion Papers and other JTRC activities, please email:

itf.contact@oecd.org

The Discussion Papers can be downloaded from:

www.internationaltransportforum.org/jtrc/DiscussionPapers/jtrcpapers.html

The International Transport Forum's website is at: www.internationaltransportforum.org

This document and any map included herein are without prejudice to the status of or sovereignty over any territory, to the delimitation of international frontiers and boundaries and to the name of any territory, city or area. 



\section{Table of contents}

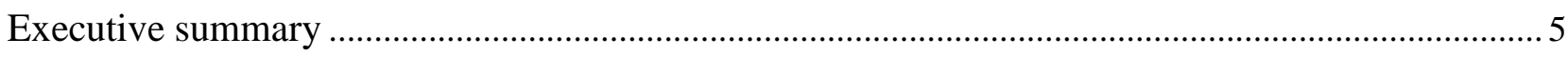

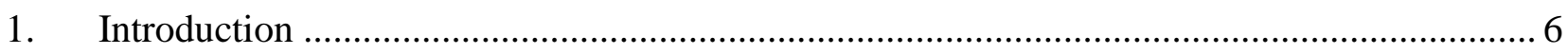

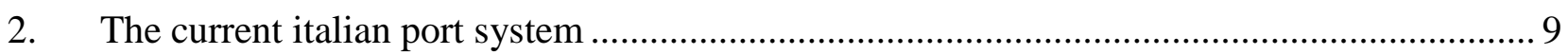

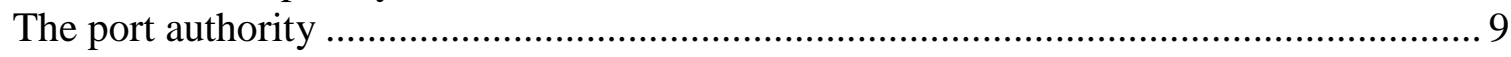

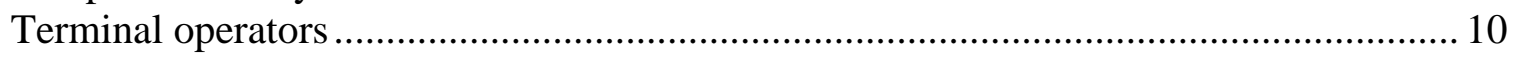

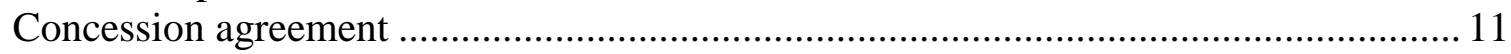

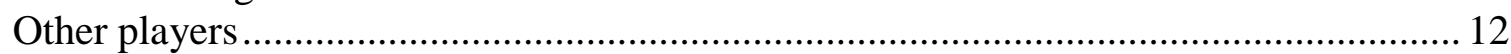

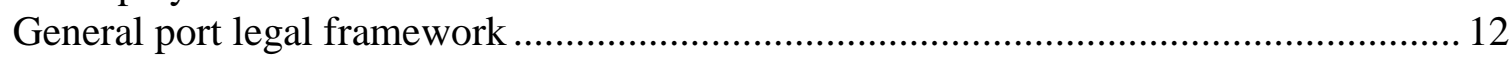

3. Port competition in italy and the international influence ........................................... 16

4. Italian port system in the european context .............................................................. 17

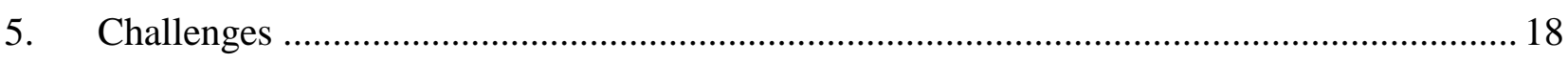

6. Proposals for a new national port organisation .......................................................... 20

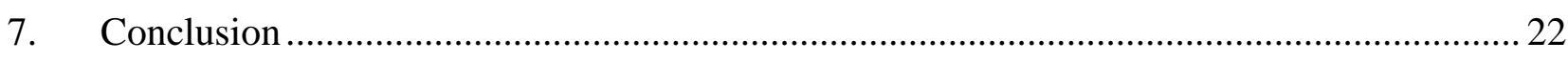

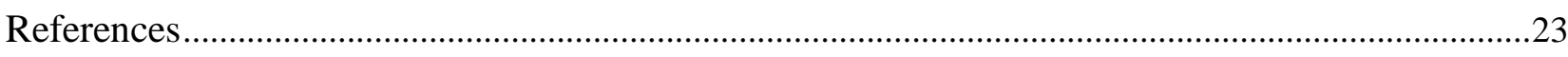

\section{Tables}

1. Breakdown of cargo traffic for the main Italian seaports $(\%)$ .8

\section{Figures}

1. Italian port system .6

2. Trend of main traffic categories of the Italian port system (2006-2012) ............................................

3. Financial income structure of the Italian port system...................................................................... 14

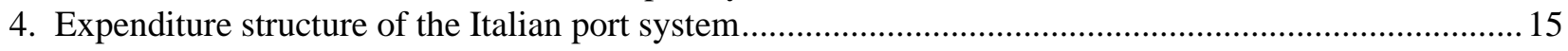

5. Container traffic development of selected Mediterranean ports..........................................................2 20 



\section{Executive summary}

The position of ports in Italy is under threat. Its main transhipment ports, Gioia Tauro and Taranto, have lost market shares to Algeciras and Valencia, whereas the catchment areas of the main gateway ports in Italy (as the Po valley) are increasingly contested by north European ports.

This loss of competitiveness of Italian ports is mainly related to the way they are governed and regulated. The main regulatory framework for ports dates back to 1994 and is not adapted to deal with the current situation. Main challenges of Italian port governance relate to the small size of ports, poor coordination of port hinterland connectivity and limited financial autonomy.

The Italian ports system is fragmented. It consists of a multitude of small ports characterised by scale inefficiency and limited market power vis-à-vis global terminal operators. A first step towards more economies of scale in the ports sector might be facilitated by cooperation of regional ports in organisations like "Ligurian ports" and the North Adriatic Ports Association (NAPA). These forms of cooperation have led to more coordinated regional marketing and promotional activities, but do not cover the core activities of port authorities. The poor coordination of port hinterlands is related to the impossibility for port authorities to control and plan anything outside the port boundaries. However, the quality and smoothness of hinterland connectivity has become one of the most important determinants of port competitiveness.

The Italian government is currently discussing a possible port reform, which could address these challenges. As part of this reform it has been proposed to merge the ports located close to each other (e.g. Genoa, Savona and La Spezia). In addition to that, one of the proposals under discussion would replace the port authorities with a few logistics authorities that should be organised according to the hinterland region they operate in, merging seaports, inland ports and other infrastructures in one public body that should coordinate the main transport and logistics providers and infrastructures.

This reform proposal deserves support. Its approval and smooth implementation could concentrate and rationalise the ports system and attract additional cargo and investments. The creation of a few functional logistics authorities would provide promising perspectives to coordinate optimal freight flows.

The creation of the regional logistics authorities should be accompanied by more financial autonomy. This could result in more efficient investments in the necessary infrastructures and more incentives for performance. In addition, port concession agreements should be strengthened, in particular by increasing their flexibility, their power to align terminal operators to port strategies and by introducing performance indicators, such as realised cargo volumes. 


\section{Introduction}

Italian ports handled approximately 460 million tonnes of cargo in 2012 according to the last statistical report of the Italian Association of Port Authorities ${ }^{1}$ (Assoporti, 2014). This is more or less the same amount as the port of Rotterdam alone. The cargo handled at the port of Antwerp - the second largest port in Europe - was equivalent to the amount of the biggest five Italian ports. This picture is illustrative of the current Italian port situation in which 24 Port Authorities (PAs), established by the port law (nr. 84/1994), are considered main national gateways even if most of them are only small ports compared to the main international competitors. Only four out of the 24 PAs surpassed the 30 million tonnes in 2012 and only 2 of them (Genoa and Trieste) have frequently handled more than 50 million tonnes in the last years. On the other hand, in 2012 passenger transit accounted for almost 40 million passengers, due to the role of home ports of some harbours in the cruise sector and few ferry terminals mainly involved in the traffic to/from the islands - that make the National passenger statistics comparable with the main European competitors. Figure 1 shows the location of the Italian Port Authorities.

Figure 1. Italian port system

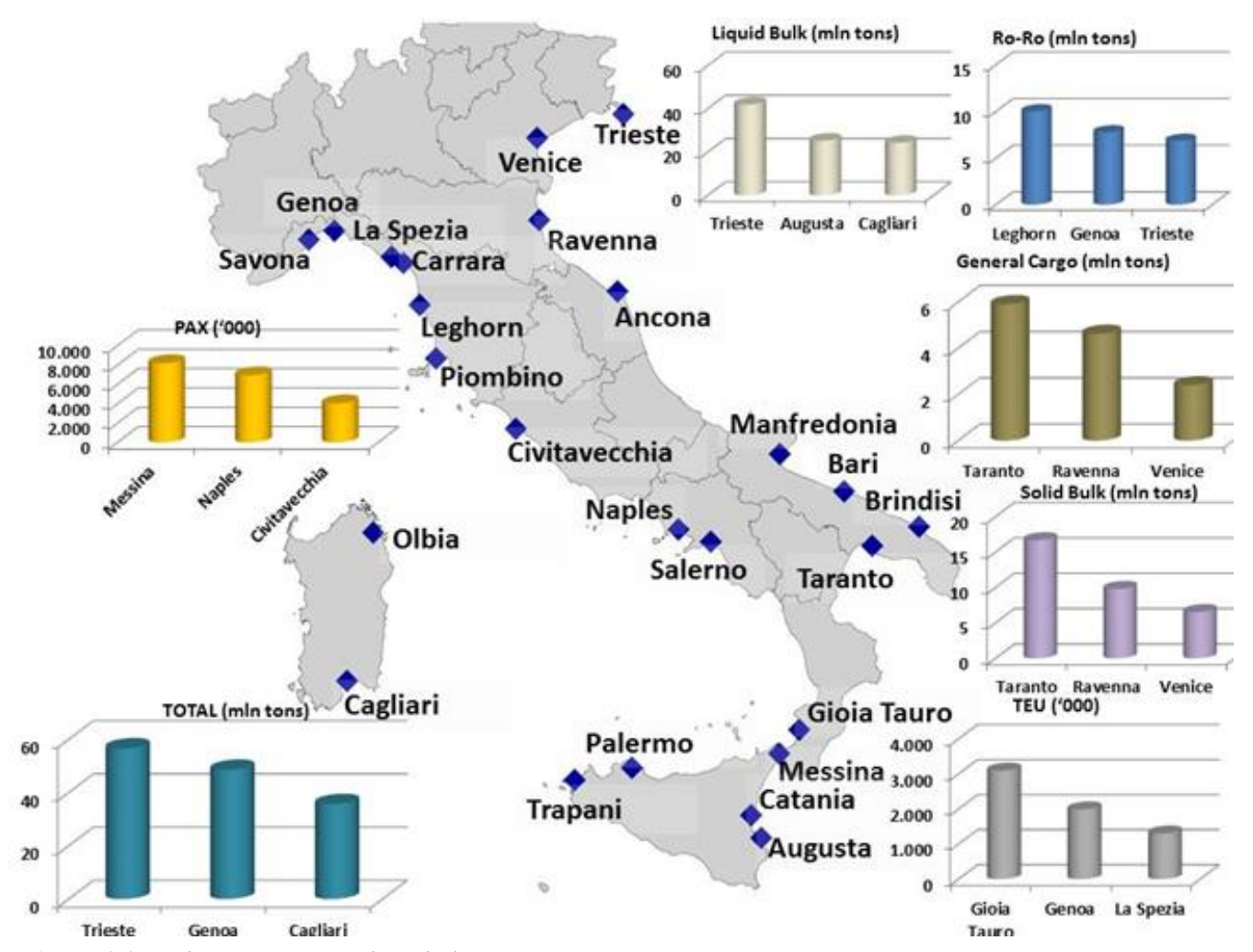

Source: Own elaboration on Assoporti statistics

1 In this contribution only national statistics have been used in order to guarantee the comparability of the figures. Several national Port Authorities use different conversion rates among TEUs, tonnes and Ro-Ro vehicles and then only statistics from Assoporti or the National Statistical Institute (ISTAT) can be considered homogenous among the ports' publications. 
Figure 2 shows the breakdown of the throughput moved by the Italian seaports registered in the last seven years. The chosen period shows the trend in different traffic categories during the three years before the financial crisis (2006-2008) and the four-year period of economic crisis (2009-2012) that is still going on in Italy. The pre-crisis levels are not still achieved yet but main traffic categories, but the liquid bulk, are slowly recovering the previous figures. The number of passengers has been affected by the economic crisis with a certain delay: in fact, statistics started to slow down in 2009, accounting in the period 20102012 for a negative growth of $12 \%$, mainly registered between the last two years.

Figure 2. Trend of main traffic categories of the Italian port system (2006-2012)

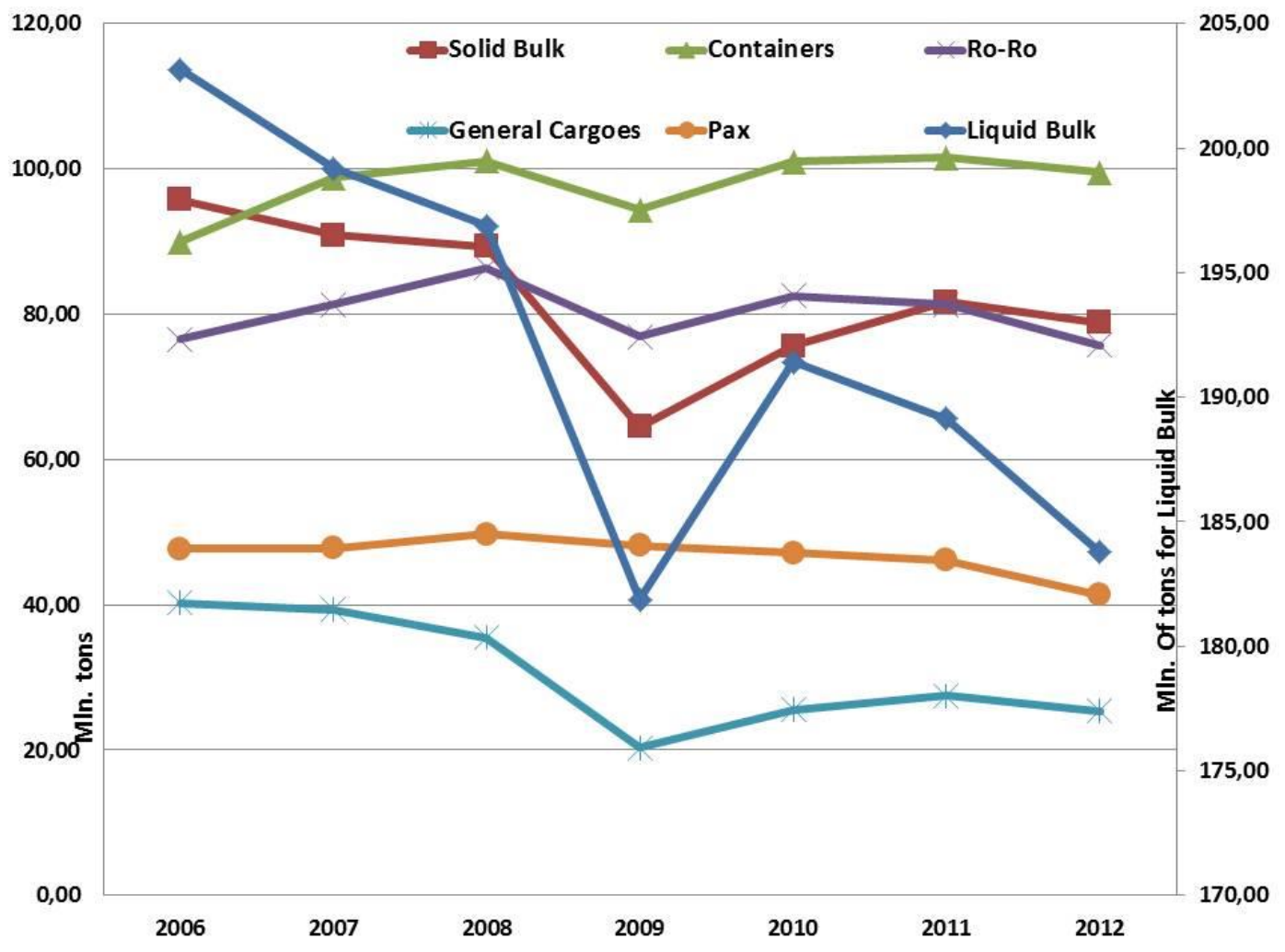

Source: Own Elaboration on Assoporti statistics, 2014.

In addition to the negative growth of the last years, a port market concentration tendency can be observed with main traffic handled by the few medium size ports currently operating in Italy. In 2012, the greatest three ports for specific traffic category handled more than $45 \%$ of the national movements for that traffic with the only exception of the Ro-Ro cargoes that registered a more balanced distribution among the ports (top-3 accounted for only $31 \%$ ).

Table 1 shows the distribution of cargo traffic per port. Currently only few ports (e.g. Genoa and Trieste) handle all the traffic typologies while the rest of the ports are specialised in one or a few cargo typologies (e.g. Marina di Carrara and Catania). Moreover, some ports act as pivot or hub for a specific kind of cargo, such as Gioia Tauro for containers, Taranto for solid bulk and Augusta for liquid bulk. 
Table 1. Breakdown of cargo traffic for the main Italian seaports (\%)

\begin{tabular}{|c|c|c|c|c|c|c|}
\hline 2013 & Liquid Bulk & Solid Bulk & Ro-Ro & General Cargoes & TEU & PAX \\
\hline Ancona & $1,9 \%$ & $0,9 \%$ & $2,7 \%$ & $0,0 \%$ & $1,0 \%$ & $2,8 \%$ \\
\hline Augusta & $14,5 \%$ & $1,6 \%$ & $0,6 \%$ & $0,3 \%$ & $0,0 \%$ & $0,0 \%$ \\
\hline Bari & $0,0 \%$ & $2,1 \%$ & $3,3 \%$ & $0,2 \%$ & $0,3 \%$ & $4,1 \%$ \\
\hline Brindisi & $1,5 \%$ & $8,1 \%$ & $2,4 \%$ & $0,2 \%$ & $0,4 \%$ & $1,1 \%$ \\
\hline Cagliari & $13,9 \%$ & $0,9 \%$ & $0,6 \%$ & $0,0 \%$ & $9,5 \%$ & $0,8 \%$ \\
\hline Catania & $0,0 \%$ & $0,3 \%$ & $6,9 \%$ & $0,8 \%$ & $0,3 \%$ & $0,9 \%$ \\
\hline Civitavecchia & $0,6 \%$ & $7,6 \%$ & $5,4 \%$ & $0,1 \%$ & $0,4 \%$ & $9,7 \%$ \\
\hline Genoa & $9,6 \%$ & $5,8 \%$ & $10,4 \%$ & $2,4 \%$ & $17,9 \%$ & $7,0 \%$ \\
\hline Gioia Tauro & $0,4 \%$ & $0,1 \%$ & $0,4 \%$ & $0,0 \%$ & $30,3 \%$ & $0,0 \%$ \\
\hline La Spezia & $0,5 \%$ & $2,1 \%$ & $0,0 \%$ & $2,2 \%$ & $11,9 \%$ & $0,5 \%$ \\
\hline Leghorn & $4,8 \%$ & $1,1 \%$ & $13,4 \%$ & $10,6 \%$ & $6,1 \%$ & $6,2 \%$ \\
\hline Marina di Carrara & $0,0 \%$ & $0,5 \%$ & $0,0 \%$ & $6,9 \%$ & $0,0 \%$ & $0,0 \%$ \\
\hline Messina & $9,9 \%$ & $0,3 \%$ & $7,8 \%$ & $0,0 \%$ & $0,0 \%$ & $19,7 \%$ \\
\hline Naples & $3,4 \%$ & $5,9 \%$ & $7,3 \%$ & $0,0 \%$ & $4,6 \%$ & $16,7 \%$ \\
\hline Olbia-Golfo Aranci-P.Torres & $0,3 \%$ & $2,3 \%$ & $6,7 \%$ & $0,0 \%$ & $0,0 \%$ & $8,8 \%$ \\
\hline Palermo-Termini Imerese & $0,4 \%$ & $0,3 \%$ & $7,2 \%$ & $0,0 \%$ & $0,2 \%$ & $3,9 \%$ \\
\hline Piombino & $0,0 \%$ & $5,7 \%$ & $0,9 \%$ & $3,0 \%$ & $0,0 \%$ & $7,4 \%$ \\
\hline Ravenna & $2,5 \%$ & $14,3 \%$ & $1,6 \%$ & $22,0 \%$ & $2,3 \%$ & $0,2 \%$ \\
\hline Salerno & $0,0 \%$ & $0,1 \%$ & $8,9 \%$ & $4,4 \%$ & $3,1 \%$ & $1,4 \%$ \\
\hline Savona & $3,7 \%$ & $4,9 \%$ & $2,7 \%$ & $4,2 \%$ & $0,6 \%$ & $3,1 \%$ \\
\hline Taranto & $2,4 \%$ & $24,3 \%$ & $0,0 \%$ & $28,1 \%$ & $1,6 \%$ & $0,0 \%$ \\
\hline Trieste & $24,0 \%$ & $1,4 \%$ & $9,2 \%$ & $3,4 \%$ & $5,6 \%$ & $0,4 \%$ \\
\hline Venice & $5,7 \%$ & $9,5 \%$ & $1,7 \%$ & $11,4 \%$ & $4,0 \%$ & $5,0 \%$ \\
\hline
\end{tabular}

Source: Own elaboration on Assoporti statistics, 2014. Yellow numbers are the ports accounting for more than $15 \%$ of the traffic while orange ones accounts for a value between $10 \%$ and $15 \%$.

The data shown above suggest the main challenge of the national port system: the relatively small size of the majority of the ports. In fact, the small and scattered traffic volumes and the dimension of the facilities affect both the attractiveness for private investments and the degree of dispersion of the public interventions (and related financial flows) creating a multitude of small PAs with low market power in comparison to the global operators and characterised by scale inefficiency that impacts on the terminal productivity. Furthermore a relatively old legislation (in force since 1994) reduces the possibility for the bigger PAs to exploit their advantages due to the limited financial autonomy of ports, the interference of politics in the port strategy choices and the impossibility to integrate port policies along the logistics chains. This issue is reducing the possibility to increase port performance or to create real competition among the several national PAs. All these problems are currently decreasing the competitiveness of the national port system, in comparison to main European competitors, affecting the possibility to enlarge port catchment areas, as discussed in Ferrari et al. (2011). In fact, this critical assessment of the current model and proposals for future changes can be found in recent national and international literature aiming at finding a solution to the current decrease in competition of the national port system. Among the many contributions Carbone and Munari (2006) described the critical issues of the current port law, Ferrari and Musso (2011) commented the on-going proposal for the modernization of the port organisational model, and Parola et al. (2012) provided a description of the main governance tool (i.e. the concession agreement) currently used by the PAs to plan and enhance the port activity.

This report aims at describing the Italian port system, discussing the critical issues and their possible solutions. Moreover, the several reform bills under discussion at the Parliament are considered, underlining the consistency of the proposition with the highlighted port related problems. Official statistics and bills together with an in depth literature analysis are used. The report is organised as follows: after this brief introduction, section 2 focuses on a description of the current Italian port legislation and its effects on the port organizational model. Section 3 is dedicated to the description of the current port market organization and on the influence of EU legislation on the port system; while section 4 discusses current critical issues 
in the Italian port model in comparison to the answers recently provided by the proposed reform bills. Section 5 addresses conclusions and identified possible avenues for further analysis.

\section{The current Italian port system}

Italy currently has 24 main ports, each managed by a Port Authority. The current port system derives from the reform law voted in 1994. Prior to that reform, Italian ports were ruled by public entities entitled to directly operate within and outside the port boundaries. At that time Italian ports resembled the typical "public port" model as depicted in the World Bank report (World Bank, 2001). In that model, ports are entirely publicly managed and private operators are only few exemptions: all the port infrastructure and services are provided by the public authorities.

As underlined in Parola et al. (2012) at the beginning of the '90s main ports registered high debt load rate. The high state debt decreased the financial transfers to the ports and a decrease in productivity - with an excess of labour force - which gave rise to a new organisational model. This was also urged by the wide diffusion of containerised cargoes that pushed ports to heavily invest in new terminals, turning a traditional labour intensity activity - as port cargo handling was - into a capital intensive one in which productivity and terminal efficiency became the key issues to compete with other ports.

These critical issues happened in the same period in which the European Union (EU) pushed Italian governments to increase competitiveness in the transport sector. Until the 1994 no-competition between port services was possible due to the chosen organizational model (Righetti, 1987). Few exemptions can be found in the biggest Italian harbours, such as Genoa, in which specific agreements between the Port Government body and some private companies were established in order to expand the original port basin or to better connect industrial berths to the factories.

At the end of the 1994, the new port law (n. 84/1994) drastically changed the port organisational system. "Public" ports were replaced by landlord ports in which PAs were in charge to coordinate, promote and plan the port activities with a specific prohibition of any directly involvement in port operations. According to this new port model the areas have been awarded to private stevedoring operators entitled to operate under a concession agreement that gives them the right to have an "operational monopoly" in those areas. Therefore the two main port actors became the PA and the terminal operation company (TOC): while the former one lost its operational powers and gained administrative and planning duties, the latter one became the only port actor able to manage a terminal and to handle cargoes. In this organisational model three other factors became strategic: the group of the other port players that contribute to define the quality of the port service (e.g. labour pools, marine services), the concession agreement organisation, and the set of rules regulating the interactions among the several port actors.

\subsection{The Port Authority}

The Port Authority is a public body in charge of managing the port as a whole. With the 1994 reform the PA are in charge of plan, promote and organise the port activities without the possibility to have an active role in the terminal operations. The PA has also a control power on the managed areas, having the right to check the respect of the several agreements signed with the private port operators and to award new areas. Safety and security issues together with the navigation rules remains to the Maritime Authority, 
a separated entity belonging to the National Navy. Moreover, PA's jurisdiction is limited to the port boundaries and normally any PA cannot promote interventions outside the ports. Similarly, each PA cannot directly intervene in some aspects of the port life that are under the jurisdiction of other authorities (e.g. customs, Maritime Authority, Sanitary Authority). Currently, there are 24 PAs in Italy but since the 1994 the number of PAs has frequently changed between a minimum of 16 and a maximum of 26, due to the changing trade-offs between the benefits of having bigger organisations and the willingness of autonomy of the smallest harbours.

Each PA is ruled by two main organisms: the President - chief of the port organisation - and the Port Committee. The President is chosen by the Transport Minister from a set of three names decided locally by the City Council, the Chamber of Commerce and the Region, and he is in charge of all the actions made by the PA. The Port Committee is a collective body representing the public and private players directly or indirectly involved in the port activity (e.g. customs, stevedoring operators, city mayor, representative of the regional government, railways, shippers, carriers) and it accounts for about 20 members. The Port Committee is a discussing arena focusing on the proposals received by the President or by other members of the committee, while the President has the power to execute the committee's decisions and to propose and promote the port plans. The planning and promoting powers are mainly exploited by the PA with two strategic and policy tools: the Triennial Operative Plan (POT) and Regulatory Port Plan (PRP). The former is an operational plan aiming at providing medium term targets and at rationalizing the investments while the PRP represents the long-run strategy of the port. These plans, as all the decisions made by the PA, can be proposed by the President but they must be approved by the Port Committee. The heterogeneity of the committee composition and the possible internal conflicts of interest were some of the causes that slowed down the decision processes, and the related investments, in several ports (Ferrari and Musso, 2011). Moreover, the role of the President - mainly as simple executor of the decision made by the Committee is currently under discussion because of the impossibility to make quick interventions to adapt port plans to the changing market cycle; the Port Committee meets usually every month (as stated by the art. nr. 9 of law 84/1994).

Eventually, as mentioned above, the average size of PA - mainly in comparison with other European competitors - appears too small in order to attract major investments or to exploit potential economies fo scale. With the increase of the average ship size and then the needed loaded and unloaded cargo flows, terminal size became even more strategic in order to compete in the international market (Ferrari et al., 2013). These are some of the main critical challenges characterising the national ports system.

\subsection{Terminal Operators}

After the 1994 private companies can operate within the port areas bidding for dedicated berths and yards that are awarded by the PA through competitive procedures. Before 1994 the majority of the terminals were multipurpose; the adoption of the landlord model facilitated several (private) investments to specialise berths and yards. At the initial stage of the reform, many terminals were awarded to local operators but through the years several global stevedoring companies entered into the sector (e.g. PSA, APM, MSC, Carnival, Grimaldi) in all the main traffic categories. However, one of the main operational limitations, introduced in order to guarantee intra-port competition, is that once installed in a port, each terminal operator can hold only one specific concession agreement for each traffic typology within the specific port. This rule was introduced by the regulator in order to favour the investment of a plurality of stevedores, reducing possible entry barriers by the incumbents. This regulation has a twofold disadvantage: it might either prevent terminal operators to acquire a technical efficient size or push terminal operators to ask for oversized terminals due to the impossibility to add an additional concession.

In recent years, several shipping companies developed verticalisation strategies and acquired shares of the main terminal in several ports. This strategy - normally adopted for new terminal investments or for 
terminal belonging to the biggest Italian ports - pushed operators to ask for increasing performance along the entire logistics chain and then for an increase in the efficiency level and coordination with other transport infrastructure of the port. The integration through the logistics chain is a topic widely studied in the literature (e.g. Notteboom and Rodrigue, 2005; Van der Host and De Langen, 2008) but the limited functional jurisdiction of the PA - in terms of space and collateral actions - often caused several bottlenecks, mainly in terms of increasing dwell time (Ferrari et al., 2013) and the inefficiencies for the logistics chains. This regulation prevents a proactive role of PAs in improving the smoothness of the logistics flows, thus determining an increase in delivery time of freight.

Recently these bottlenecks, together with the lack of a coordinating strategy between the port area and the port hinterland, have been identified by the private operators as some of the main threats for the Italian port system.

\subsection{Concession Agreement}

Concession contracts represent the most important instruments that a PA has to directly affect the management of port activities. As stated in Parola et al. (2012) and Notteboom and Verhoeven (2009), in the landlord model the PA can bargain with the terminal operator to reach some specific goals. This may happen when the port area has yet been assigned to a private company (e.g. a pure terminal operator, a vertical integrated carrier), or during the renewal stage of the agreement if it is foreseen in the concession agreement (Theys and Notteboom, 2010). In general, once a terminal area has been awarded, the concession contract sets the "rules of the game" (also in terms of investments) of both the actors involved: the stevedore operator and the PA. For this reason, several papers have focused their attention on this kind of contracts highlighting critical issues related to their structure (e.g. Pallis et al., 2008), duration (e.g. Notteboom and Verhoeven, 2009), awarding process, (Theys and Notteboom, 2010), and about their impact on the port competitiveness (e.g. Kaselimi et al., 2011). All the papers underline the need for a transparent and effective concession policy mainly because changes through the concession period are quite hard to realize. Apart from the general framework, as discussed in Notteboom and Verhoeven (2009) each EU country has several differences in the application of the concession policy.

For instance, port concession agreements in Italy are public acts through which the PA awards the right to operate to a private company a defined activity in a certain specific port area. Because of the "public act" nature, changes cannot be made to the act until its expiration (Brignardello, 2010). Through the concession agreements the PA establishes the number of port players allowing them to act as monopolists on their own awarded area. For this reason, the concession agreement is also accompanied by an operative authorisation. This latter act gives the right to effectively operate the activity following the common port rules. Moreover, no private companies can hold more than one concession in the same port having the same activity as primary scope (e.g. there can be more than one container terminals but they cannot belong to the same company). Currently, main ports are characterised by the majority of port areas conceded to private companies: for instance the majority of Italian PAs have awarded more than $60 \%$ of their space with peaks of about $90 \%$. This issue is also linked to a series of organizational problems mainly related to the increase of operative authorizations and small sized concessions in the major ports. For instance, some ports manage more than 1,000 concessions and authorizations, just because the same operator establishes ancillary activities in the port and for each of them he asks for a different concession agreement.

Before the '94, port law defined areas under concession as an exemption and they were allowed for period shorter than five years. After 1994, concessions were the most common policy tool used by the PA. This change structurally impacted also on the financial importance of the entrance by concessions in the PA balance: until the end of the ' 90 s concession fee, on average, accounted for less than $10 \%$ of the PAs' current incomes while that value was doubled around the mid 2000s (Parola et al., 2012), becoming the 
second largest current financial entrance. Currently concession fees are not proportional to the terminal performance but are calculated as a normal rent based on the real estate value of the particular port area, as described in Ferrari et al. (2013).

The impossibility to modify the concession act affects the flexibility of the terminal activity: once detailed the terminal characteristics and activity only a new concession can change them. The duration, the renewal procedure and the decision of the terminal operator's goals are then essential for the port development. For all these aspects competition authorities (e.g. AGCM, 1997) made several warnings about the effects of inefficient decision processes on these topics. The duration, in fact, affects both the amount of private investments and the possibility to modify the terminal structure and its characteristics this latter aspects is mainly based on the rigidity of the act - while the renewal procedure is a potential barrier for the terminal competitors that may affect the whole port performance. Currently, terminal concessions last from more than 25 years, on average, with peaks of more than 60 years. Renewal procedures were rare in the past, mainly because first concession agreements started about 20 years ago. The decision of the terminal goals is linked with the choice of an effective awarding process: the first concessions have been given through public procedures but without an effective public tender. These procedures facilitate local companies but not the transparency and the effectiveness of the process. Thus, goals were not settled by the PA but they are currently based on the promised traffic of the terminal operator with few controls on the real terminal potential capacity. Only recently have general public procedures been officially substituted by international public tenders, but relatively few clauses or targets have been inserted by the PAs and terminal performance targets are normally based on the presented business plans and a forecasted scenario, rather than on real throughput.

\section{4 "Other players"}

The Port Authority and the terminal operator are only two actors among the several players operating inside the port. While PAs and TOCs represent the port core business and activity, in general each port has a constellation of many other companies and authorities that are functional and strategic in order to realise port services. It is possible to divide these actors into two categories: private companies working through special authorizations and public authorities. The former group is composed of companies operating in a competitive monopolistic market - regulated by the Ministry and justified by the several safety and security issues related to these activities - and their aim is to provide essential services, functional to the PA or TOC work. Among these actors are the port railway company, the marine port services providers (e.g. mooring, towage) and the labour pools. Among the public authorities working in the port, there are the customs and the sanitary related authorities entitled to control and check the goods passing through the port gates.

In general, the PA has a coordinating role among all these players, carried out through the Port Committee. Nevertheless the different controlling levels of the authorities have created several critical issues in terms of coordination and modernization among the port processes and procedures (Ferrari et al., 2013), e.g. customs are controlled directly by the central government offices. Moreover several actors, especially TOCs and shipping companies, have pleaded for a market liberalization of many legal monopolies - in particular marine and transport services - due to their strategic role in the organisation of the logistics cycle (Bottasso et al., 2013).

\subsection{General port legal framework}

The organisational model of Italian seaports is ruled by the $n .84 / 1994$ law but several other aspects are ruled by the Code of Navigation (issued in 1942 and modified several times); moreover other new rules have seldom been inserted in the annual financial laws (e.g. the financial law for the year 2006 deeply modified the income structure of PAs). It is possible to group the main rules defining the Italian port 
organisation into six categories: decision power (i), financial structure (ii), internal market organisation (iii), hinterland organization (iv), investment (v), and possible horizontal and vertical interaction (vi).

Concerning the decision power, Port Authorities share it with the public authorities (e.g. ministries, customs and regional governments) due to the need for coordination among all the other rulers of the entire transport and logistics chain. PAs can rule, plan and organise the transport activities only inside the port boundaries even if many actions ask for coordinated operations also outside the port. Furthermore, many activities have to be controlled by other government agencies (e.g. customs) and then any administrative and procedural rationalization has to be decided together with the other player. Moreover, the rigidity of the concession agreement - due to its nature of administrative act - imposes that any changes in the areas under concession should be bargained with the private company that operates on it: apart from bureaucratic constraints there can be also operational constraints. PAs can promote and plan the port but they have a limited actual decision power in respect of the many limitations given by the other subject operating within the port.

The port's financial structure is mainly determined by four main revenue sources: public funding, loans, taxes and concession fees (figure 3). Public funding is an heterogeneous category that grouped different financial statistics mainly related to the public investment programs for general infrastructures or activities (e.g. strategic facilities serving ports and hinterland, dredging) that cannot be financed by the ordinary PA's budget, and current transfers for the ordinary activity. Loans were the main financial instruments until the 1994 port reform, but these represent a complementary source of finance, used to cofinance infrastructures when public funds cannot cover all the value. Currently the main revenue sources are taxes and concession fees. Taxes are divided in two main categories: a port tax - calculated on the loaded and unloaded cargo - and an anchorage tax - calculated on the ship tonnage calling at the port. Concession fees are the amounts paid by private operators in place of the right to operate inside the port area. They are normally based on the real estate value of the area with little relation to the terminal performance. Thus, both the value of taxes and concession fees depend on the port configuration and on the presence of many terminals but only taxes are related to the port traffic. While concession fees are directly collected by every PA, the taxes are collected by an intermediate agency: the Customs. This structure of the current income makes PAs highly dependent on the central government for public funding and reduces the autonomy of PAs due to the shortage of current income in respect of the biggest investments. Since many Italian ports do not generate enough current income, the national government cross-subsidises ports in order to allow the survival of the national ports system. An extreme case is Gioia Tauro, one of the biggest transhipment ports in the Mediterranean, that due to the low concession fees and relative few number of calls does not generate enough current income, requiring frequent public transfers in order to keep the port operational: according to the annual reports of the port authority of Gioia Tauro, public transfers frequently represent more than $50 \%$ of the total current income of Gioia Tauro (e.g. Torbianelli, 2013). 
Figure 3. Financial income structure of the Italian port system

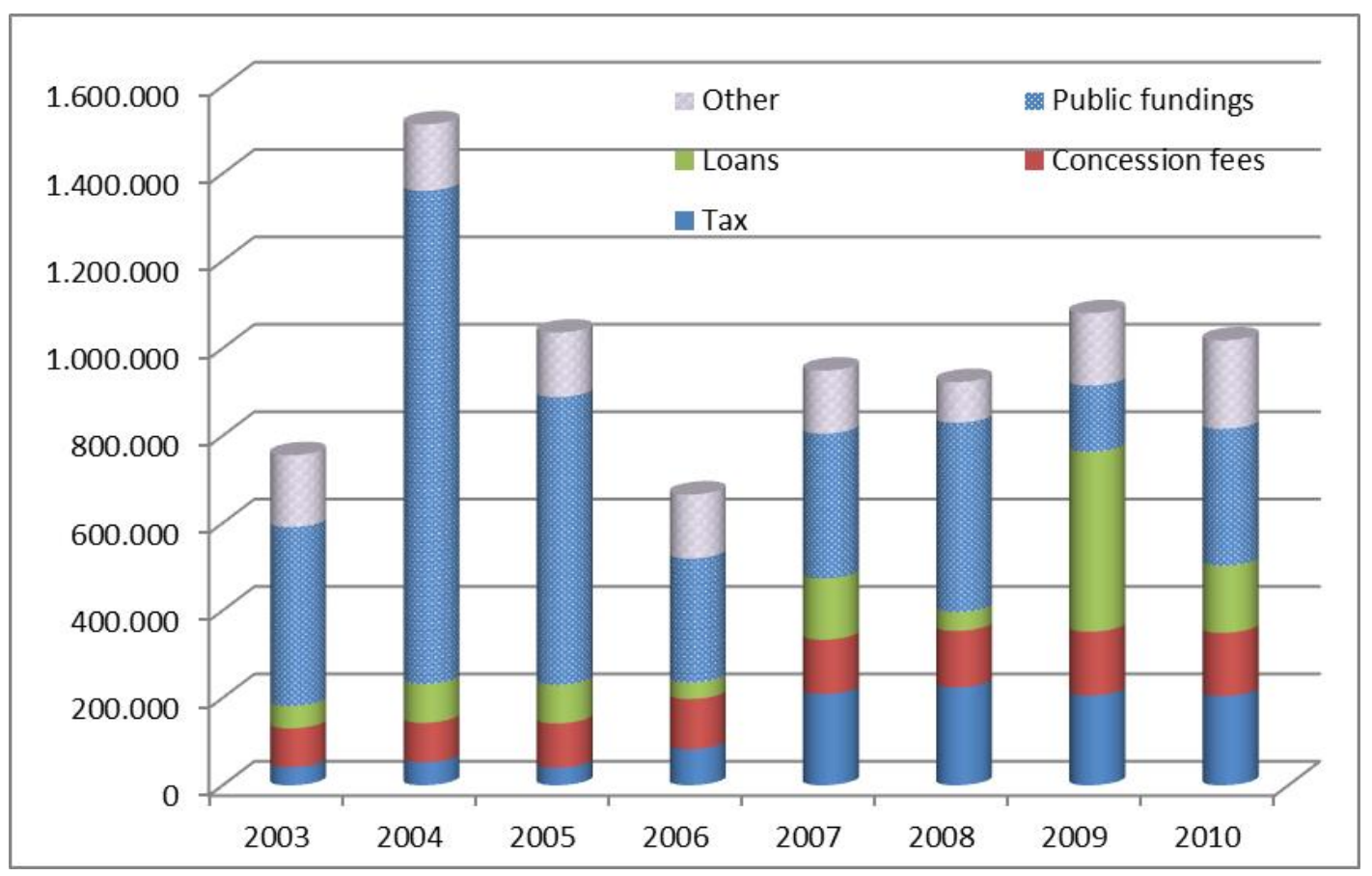

Source: Own elaboration of Ministry of Transport Statistics, 2014. Data in thousands of euros.

Each port has a complex internal market organisation in which the PA acts as a market controller among the private companies operating within its jurisdiction but the intra-port competition is normally low. In principle, port areas are awarded through a competitive process that only in late 2000 has become an international bid. Starting from 1994, main terminals have been awarded through public calls in which the stevedoring already operating in the terminal had a clear - and often even recognised - advantage in comparison with the potential competitors. Moreover the long duration of the terminal concessions longer than 20 years, according to Parola et al. (2012) - and the low number of new terminals opened since 1994, strongly reduced the potential competition among different stevedores. Together with the stevedoring market, other ancillary industries register a lack of competitiveness with legal monopolies such as the marine services and labour pools - often studied by the national competition authority (e.g. AGCM, 2014) that had doubts about the current market exemptions. The lack of intra-port competitiveness has been extensively discussed, associating it at either an increase in terms of costs (Costa and Casagrande, 2011) or a substantial increase in terms of quality and productivity (Bottasso et al., 2013) in comparison with other European ports.

The low degree of financial autonomy and constrained planning jurisdiction strongly limit the possibility of coordinated policies over the port hinterland region or the potential catching area. This issue, considered as one of the main competitive determinants for modern ports (e.g. Rodrigue and Notteboom, 2005; Van der Host and De Langen, 2008), represents the main limitation of the Italian port system. The impossibility to plan or promote investments or activities outside the port boundaries has become one of the main challenges mentioned in political debates about a new reform, aiming at the introduction of logistics authorities capable of spreading their planning and promoting activities along the whole logistics chain, from the port to the hinterland and independently by the chosen transport infrastructure.

Investments are strictly linked to the decision making process and the financial source. The centralization of many of these issues limits the possibility for PAs to quickly respond to the market 
demand for newer and more efficient port infrastructure (e.g. Cesaroni and De Stefanis, 2014). For this reason, several dedicated investments for private terminals are normally made by private operators, often in exchange of discounts on the concession fees or because they were included in the concession agreement. Despite these private investments, most of the expenditures of PAs are investments in upgrading the general facilities (e.g. common transport infrastructure) and port physical characteristics (e.g. dredging). The instability of ports' expenditures derives from the unpredictable financial flow received from the central government.

Figure 4. Expenditure structure of the Italian port system

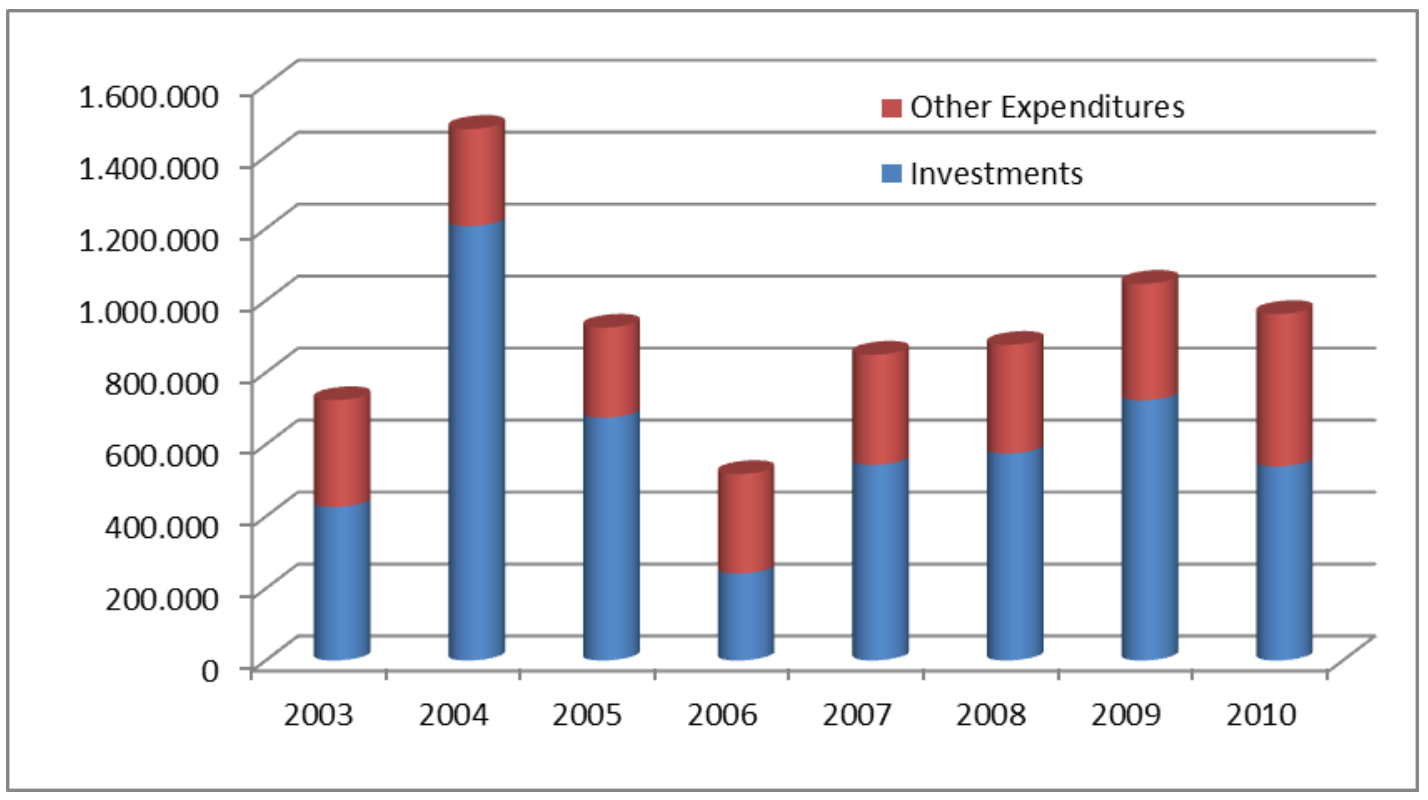

Source: Own elaboration of Ministry of Transport Statistics, 2014. Data in thousands of euros.

The efficiency of the abovementioned framework is influenced by the current tendency towards horizontal and vertical integration. Many shipping and stevedoring operators are involved in horizontal integration; as a result the market is now dominated by big global players with large market concentration as a consequence. The current port legislation provides no limitations for terminal ownership in different ports in the country and no coordination on this issue is provided. Thus small-sized PAs have to bargain with ever increasing terminal and shipping companies that own a great market power and multiple interests in several ports limiting the possibility for a PA to intervene. In general, central government control is not translated in national coordination among the PAs, which reduces both the competition among the ports and the possibility to have a systemic approach. In addition, vertical integration increases both the market power of private companies and the need for integrated policies along the transport chains, at odds with the "old fashioned" organisation of the current PA system. According to Ferrari et al. (2011) this circumstance is one of the main threats currently experienced by the Northern Italian ports and it is negatively affecting the Italian ports' catchment areas. In fact, the authors underlined how several central European markets are served by the Northern European ports despite the geographical location of some Italian competitors, as a consequence of the underperformance of the Italian transport and logistics chain. 


\section{Port competition in Italy and the international influence}

Is there port competition in Italy? It depends on how you look at it. While intra-port competition almost does not exist (with some exceptions), largely depending on the awarding processes used to assign the right to operate in the market (e.g. giving the terminal concession or the right to be the marine service monopolists); inter-port competition depends on the size and of the hinterland served and on the specific markets of the handled goods.

Given the impossibility for many ports to establish intra-port competition among terminal operators mainly due to their small size -, together with the legal monopoly given to the marine service and labour providers, the competition within the port boundaries is provided only through the awarding processes. The terminal awarding process has, since the 1994 and until the end of the last decade, been guaranteed by public procedures in which a PA publicly looked for private companies interested in establishing a specific activity - previously decided by the port committee - in a certain port area. In case of more than one single offer, a comparison between the offers was based on the business plans. According to Parola et al. (2012), few actual controls on the promised values included in the business plans have been traditionally made and the small size of the ports often decreased the PA's bargaining power with the global stevedoring operators, also limiting possible requests for an improvement in business plan. At the beginning of the port reform, the public procedures gave an advantage to the incumbents that already knew the PA strategies and the port characteristics; and that moreover already had a representation in the port committee. The long duration of concessions influenced the rigidity of the port structure and organisation, reducing the possibility for newcomers to invest in the Italian port system. Starting from the mid-2000s, and in compliance with the EU legislation improvements (e.g. Directive n. 2004/17/EC recently modified with the Directive 2014/25/UE), competitive bids were established in all the main Italian ports. The long term of the previously awarded concessions, and the lack of new investments, substantially reduced the number of terminals given through a bid. Moreover, as stated by some authors and public reports (e.g. ITMMA, 2008), renewal of concessions are considered reasonable in case of new investment, in order to guarantee the "right return of the investment made". This possibility is currently under debate because it can negatively influence the potential competition given by the awarding process or the benefits of a new investor. This characteristic, together with the administrative problems (I.e. the coordination among the public authorities involved in the port operations), has contributed to a reduction of the investments and several efficiency challenges, such as an increase in dwell time (that in some cases over passed two weeks during the peak periods). Some of these problems have been recently linked to the mixed power of the PA that is acting at both a planning body and a control agency within the port, reducing its effectiveness in doing both jobs (e.g. AGCM, 2014). On the other hand, marine service and labour pools act in regulated monopolies with tariffs regulated by the Ministries through a methodology similar to the Rate of Return. Companies have an authorisation to operate as monopolists in the port given through a public procedure but the lack of competition has been raised by the Italian Competition Authority (AGCM, 1997) even if such organisation should guarantee fair fares and a high quality level of services, as argued in Carbone and Munari (2010).

Concerning the inter-port competition, several overlaps characterise the hinterland regions and the catchment areas of several Italian ports, as shown in Ferrari et al. (2011). The inter-port competition is 
exploited not by PAs but by the private companies able to build efficient services along the transport and logistics chains. For this reason, recently some PAs' Presidents tried to promote collaborations among different transport and logistics players, such as inland ports, logistics parks and railways companies; e.g. the Genoa PA is trying to establish a durable collaboration with the inland ports located close to Milan and Turin. As such, PAs try to act as port cluster managers but, due to the legislative constraints, main actions are dependent on personal perseverance and initiatives. Only private companies have a structural active role in the logistics chains development with main consequences related to the increasing power of integrated operators - normally represented by global carriers with only few exemptions - that are radically affecting the distribution of cargoes in the Italian ports. This issue is a threat to minor ports, with increasing traffic concentration in only few harbours. The consequence of competition in different catchment areas, low efficiency levels and the global carriers' perspectives is that several cargoes especially in the containerised market - have moved quite far away from the Italian ports because of the advantages that the operators can realise by moving freights to the North European ports (e.g. Notteboom and Rodrigue, 2005) and then serving the Northern Italy through the logistics corridors that cross the Alps. This issue is currently less affecting the bulk market due to the strict link with the served industries or the position of the few dedicated infrastructures, such as gas and oil pipelines, that give a competitive advantage to the operator.

\section{Italian port system in the European context}

During the last decade, several European national port systems have changed. The reasons for these changes can be found in the need for an efficient national gateway network able to serve the connected industrial system. Ports are powerful elements that may radically affect the economic development of a region. Even if some authors underline an overestimation of the positive effects given by the port industry (Bottasso et al., 2014), the majority of the contributions (Ferrari et al., 2008) highlight the importance of having an efficient endowment of land and sea-related transport infrastructures. For this reason, the European Union (EU) included ports in its transport strategy for the long term growth (e.g. TEN-T strategy) and tried to promote maritime related policies (e.g. Motorways of the Sea) even if the EU has so far not managed to achieve implementation of a common port legislation, despite multiple attempts (e.g. Bergantino, 2002; Parola et al., 2012; European Commission, 2013). Currently, apart from some general guidelines and directives regulating issues that may affect the port activity (e.g. the public investments rules, market competition legislation), port legislation is different country to country because each member states can relatively freely regulate its own port system. As a consequence, several port organisational models can be found across Europe (Cariou et al., 2014). While in the UK port system either private, landlord and tool ports may be found (Baird, 2000) the most commonly applied organisational model adopted in Europe is the so-called landlord model (ITMMA, 2008). Despite the common use of the landlord model, several countries have introduced local characteristics aiming at achieving specific goals or due to cultural elements. Thus in Latin countries, public authorities - and often central governments still have a stronger role than in North European ports where many of the ports have been corporatized (e.g. De Langen and Heij, 2014).

These issues are influencing the current national debate on the port needs in terms of adapting to the EU competitors, increasing the requests for opening the market and the contrast between the Italian Transport ministry and the EU. Port communities have demanded the ministry of Transport to allow PAs to plan (and also invest into) the entire logistics corridor and the PA president to have more decisional powers 
- reducing at the same time the role of the port committee - and an increase in the PA autonomous financial endowment in order to rapidly respond to market demand. The European Commission and National Antitrust Authorities underline the lack of competition within the ports, and aim at a more strict application of the current legislation. According to the national port organization (Assoporti, 2014) and ministerial reports on the port system, Italian ports were among the pioneers in the application of the landlord model in Europe, which fostered the fast growth during the late '90s but some changes seem necessary in order to maintain competitiveness of the system. Assoporti - the association grouping together most of Italian ports ${ }^{2}$ - has frequently underlined two main differences between the domestic ports and the main competitors: $i$ ) the financial autonomy - from the central and local government - that is giving a competitive advantage to the Spanish and North European ports; and ii) a new internal organisation of the PA aiming at increasing the decisional power of the President and reducing possible conflicts inside the port committee. Some ports (i.e. Venice) have underlined the differences in market structure among the marine service providers in Europe claiming that current Italian tariffs are negatively affecting the attractiveness of the Italian ports due to current monopolies.

From the debate on the specialised media it emerges that port actors perceive that maritime and port rules are sometimes applied more strictly in Italy than in the competitor countries. For instance the implementation of the Port State Control (PSC) and the European coordination among the national custom agencies are often perceived as potential threats arguing that they are resulting in a higher number of controls made by the Italian authorities, compared to what happens in the North European seaports, and then reducing the efficiency of the whole logistics chain (e.g. dwell time) for cargoes that are loaded/unloaded in the national port system ${ }^{3}$.

The Italian legislator and all the port actors are discussing a reform bill aiming at providing a legal framework similar to those already experienced by the major port systems, in order to achieve the double objective of having a more flexible and effective planning authority, guarantee inter- and intra-port competition and enough resources to influence the whole logistics chain.

\section{Challenges}

The Italian port system is facing several critical problems. Apart from the industrial flows, decreased due to the structural economic crisis affecting the country, other freight flows' patterns are driven by several global carriers that select ports in order to rationalize their shipping network (Ferrari et al., 2013) and by forwarders and logistics providers wishing to operate in efficient transport node (Meersman et al., 2009). This trend sharpens some of the structural problems above mentioned, in particular: the average small size of the Italian seaports; the inefficiency of port hinterland connectivity, and modernization issues.

2 The Port Authorities of Genova and Ravenna, for instance, announced their exit from the Association in the Summer 2014.

3 According to the last available Annual Report of Paris MoU on Port State Control (2014) Italy is one of the leading countries in terms of number of controls made (following UK, Spain and The Netherlands). Italy records the fourth highest number of "high risk ships" inspected (following Greece, Romania and Russian Federation), and the third highest number of "standard risk ships" inspected (following Spain and UK). In general, the Mediterranean seaports record more extended inspections than the North European ones. 
Concerning the size, as shown in the first section of this report, the majority of the traffic handled by the Italian ports is concentrated in few "hubs" while many ports are small sized harbours handling few quantities of cargo. The current centralized organization and low inter-port competition guarantee enough financial resources for each port even if this situation is penalising the establishment of national poles able to compete for wider hinterlands or to attract big global operators. The agglomeration of ports serving the same hinterland under a common organisation body, could contribute to rationalise the port sector and to attract additional cargo and investments. A first step towards a similar structure is represented by organisations like "Ligurian ports" and NAPA (the North Adriatic Ports Association) dealing with marketing and promotional activities, but they are not impacting on the core activities of PAs. The financial autonomy of seaports has been claimed several times as a suitable mean to select the best practices and the ports able to survive in the market. Trade flows and investments patterns would then naturally push small PAs towards an aggregation path. However, central government seems to slow down the introduction of financial autonomy in order to keep control on the main port revenues and the possibility to divert it or to select different investments. At the same time, several small port communities fear the introduction of the financial autonomy and the eventual occurrence of being obliged to merge with other ports, as these mean the loss of control on one of the main driver of the local economy.

The connectivity issue is mainly related to the impossibility for each PA to control and plan anything outside the port boundaries while it is widely accepted that the main competitive factor for port operators stands in an efficient supply chain. In this sense the law by decree 201/2011, conforming to a suggestion of the National Logistics Plan (Consulta Generale per l'Autotrasporto e la Logistica, 2011), establishes that PAs may promote agreements with regional and local administrations and the rail infrastructure manager in order to improve the connectivity of their hinterlands. Moreover on this issue there is a proposal, currently under debate, aiming at replacing PAs with a few logistics authorities that should be organised according to the hinterland region they operate in and that should coordinate the main transport and logistics providers and infrastructures. The interconnectivity issue is strictly related to small average port size because several Italian regions (e.g. Piedmont and Lombardy) are served by more than one port and then transport corridors should be regulated and administrated by a single logistics authority even if they are served by more than one port. Interconnectivity issues represent the main competitive threat for the national economic system because they are decreasing the overall efficiency of the logistics system, thus indirectly affecting the production costs (Confetra, 2011) of Italian industries. Moreover interconnectivity problems and the lack of coordination among different networks result in an increase in the generalised transport cost for both freights and passengers and they also hamper the development of intermodality, for instance the real development of the motorways of the sea despite their theoretical advantages over the road transport (Consulta Generale per l'Autotrasporto e la Logistica, 2011)).

To overcome the lack of coordination among port players and port and transport services the port system should move towards production functions even more capital intensive, investing in new technologies. Extended Intelligent Transport Systems (ITS) or Information and Communication Technology (ICT) platforms are some of the essential gaps that several ports are currently trying to cope with. In this regard the cooperation under the "UirNet project" is making available a common web platform to all the main port actors in order to share the essential information on cargo flows. An example of this service is the pioneering project introduced in the port of Genoa, called "E-port". This system allows all the port operators to access all the information related to a specific cargo, operator or ship and once completed - also data on flows in real-time. Despite the recent development in ITS and ICT provision, efficient administrative procedures, already settled in several European ports, such as the "pre-clearing" activity, have difficulties getting implemented in Italian ports. This controversial issue is basically due to the co-existence of several authorities, with their own administrative and information system, within the port. This situation should be solved through the unification of the control and information systems - the so-called "one-stop-shop" - of the different authorities and the experimentation with a simplification of the administrative procedures thanks to an easier coordination of the several public bodies involved. An 
example is the experimentation of the pre-clearing procedures in the port of Genoa thanks to the shared information among the customs, the PA, the sanitary authority and the forwarders' association.

Since these critical issues are deeply affecting the efficiency of the national port system, during the last decades several bills have been proposed in order to up-date the port legislation. Even if they are still under debate some ideas seem rather mature and close to adoption. These will be presented and discussed in the next section.

\section{Proposals for a new national port organisation}

After two decades the stage of port growth triggered by the reform law 84/94 ended and the need for a new legislation became clear both for the legislator and also for the port managers. Evolutions in the shipping and port industries would require a new organizational scheme of seaports and a new role for the Port Authorities; and the statistics illustrate the declining competitiveness of main Italian ports. Figure 5 shows the container market trend in a sample of Mediterranean competitors, for both transhipment and gateway ports. The growth rates of main Italian ports were higher than the competitors ones until the first years of the new century when other ports started to perform better.

Figure 5. Container traffic development of selected Mediterranean ports

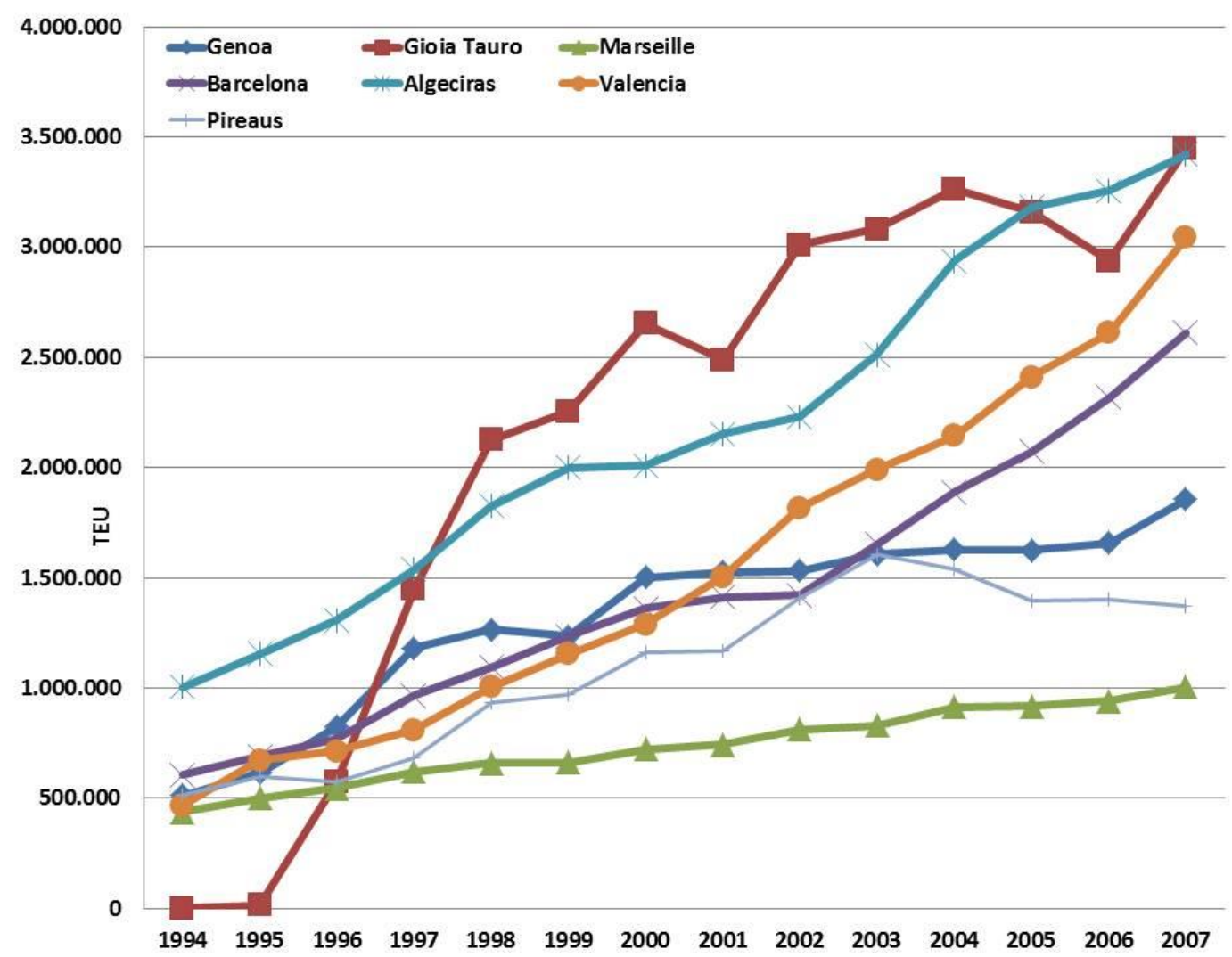

Source: own elaboration of Port Authority of Genoa database, 2014 
During the same years, the reforms applied in other countries (e.g. the Spanish one at the beginning of the new century) and the investments on transport networks in other EU regions (e.g. railway and inland waterway investments between Northern range ports and Switzerland) underlined the lack of the national port legislation. Together with these competitiveness issues, some other determinants were identified, such as the internal market organisation (e.g. the statutory monopoly for the marine services) or the potential ineffectiveness and reduced flexibility that concession agreements may have in order to push the private operators to contribute in pursuing the PA objectives or to optimize their economic performances.

These external and internal forces pushed politicians to open a discussion about a new port organization and since 2006 subsequent governments have proposed several bills, intensely analysed by the Italian scholars (e.g. Musso and Ferrari, 2011; Brignardello, 2010). These different bills have one common goal: to move the Italian port system towards the level of the North European competitors. Another common feature is the priority for reform: i) the number (and size) of PAs (ii); the possibility for a PA to plan the whole logistics corridors it uses; and (iii); the financial autonomy of PAs.

i) Size. There is a proposal for merging the ports located close to each other (e.g. Genoa, Savona and La Spezia) in order to concentrate and rationalize national investments in these ports. Moreover, related to the European TEN-T policy, a distinction between strategic national PAs and regional PAs was proposed aiming at rationalize the freight flows among the ports. These propositions are facing several local obstacles mainly due to the fear of local communities in smaller ports to lose the control of the main generator of local economic growth.

ii) Logistics Authorities. The possibility for a PA to plan and control "its" logistics corridors should move the PAs from the Latin landlord model to the role of cluster managers and in this way contribute to move closer to the flexibility that characterizes the North European ports. One of the most revolutionary proposals was to replace the PAs with regional Logistics Authority entrusted to control, plan and regulate the transport and logistics infrastructures and freight flows in a specific economic region. In these last proposals only a few functional logistics authorities would have aggregated all the seaports, inland ports and other infrastructures in a unique public body, having the chance to coordinate all the needed structures in order to optimize the freight flows. The main challenge of the proposed system was hidden behind the multitude of local and regional public and private actors to be coordinated despite their potential different interests.

iii) Financial autonomy. More financial autonomy should solve the lack of money for investments and at the same time it should make PAs more responsible of the investments they intend to do. The requests of the PAs to directly control their own finance was partially allowed in 2006 with the adoption of a new division for the port taxes collected through the ships calling port, while a new revenue source was granted to the PAs in 2013 (legislative decree nr. 83/2012) through a share of the VAT generated in the region (with a cap equal to 1\%). Despite these interventions, national government is not in favour to extend the financial autonomy of PAs mainly for two reasons: first, the economic crisis strongly weakened national revenue sources, and secondly, because the port financial autonomy was one of the main inefficiencies experienced by the seaport sector in the ' 80 s (subsequently taken into account by the reform law 84/94).

Other minor proposals have been made mainly in order to change the concession system, to strengthen the power of the PAs' presidents, to change the port internal service market and to simplify the administrative procedures (e.g. customs). 
Despite these several proposals only a few financial modifications have actually been approved. After the 2006 elections, the port system was one of the main discussed topics among parties aiming at creating the biggest "Mediterranean logistics platform" for the North-South and East-West maritime flows; despite the announcements almost nothing changed. The last bill was discussed in the Parliament during the spring 2013 but it was dropped out of the Senate.

In September 2014 the government started to officially work on a new bill that should mix the past proposals and the new standard requested by the National Port Organisation (Assoporti) even if no official news have been provided yet. In accordance with the legislative decree nr. 133/2014 the Government has recently announced the creation of a Committee in charge of defining the National Strategic Plan for Ports and Logistics (expected for February 2015) that will inform a new port reform bill.

\section{Conclusion}

The Italian port system is made up of several small sized ports with only few exceptions. These ports are currently regulated and controlled by a public body - the Port Authority - that should promote, plan and optimize the performance of the (private) port players. Despite the objectives, PAs have today several administrative and financial limits that hardly allow them to achieve their own goals.

While politicians are discussing about the numbers of ports or their hierarchy (e.g. international vs regional ports) and other aspects, the discussion about a reform bill is still unfinished, and only marginal changes have been added to the current law during the last twenty years. The ports' organizational system reflects the market organisation of the early ' $90 \mathrm{~s}$, but trade patterns, shipping technology, the maritime industry and ports have evolved hugely since then. The port system in Italy is currently confronted with several gaps. The organisation is based on the landlord model with the PA that is not only a regulator but also the port planner even if with restricted powers. The small average size of ports reduces the possibilities for the intra-port competition and the modernization processes of the port procedures are slowed down by the several authorities currently operating in the port.

Attempts to introduce structural changes have so far failed, but would still be needed. In the meantime, a second best solution could be the adoption of few specific modifications. For instance, one of these temporary solutions could be to strengthen the effectiveness of the concession agreements making them more flexible and easy to use for binding PAs' plans with those of the port operators, using actual performance indicators. In this way the proposals discussed by Puliafito et al. (2013) and underlined by Wang et al. (2014) to use the concession fee as dynamic incentive to achieve certain goals appears easy to implement, at least until a structural port reform will be voted.

The structural reform of the model of port governance should take into account also the whole logistics corridors, mainly because hinterlands and catchment areas need to be efficiently connected with the ports in order to compete and carry out positive economic benefits. Moreover port and shipping companies compete in several markets along the whole logistics chain, often under several regulation authorities that affects their possibility to exploit all their potential. The new legislation would promote a homogenization of the legislation along the logistics corridors, increasing the overall efficiency level. 
The lack of adjustment to the current structure of shipping industry and logistics players is resulting in two on-going threats: the continuous loss of competitiveness of the national transhipment ports (e.g. Gioia Tauro and Taranto in comparison with Algeciras and Valencia) and the shrinking of the catchment areas of most gateways ports (e.g. Rotterdam is currently serving the Po valley). Both these trends could be reversed by the introduction of some of the mentioned propositions: the introduction of logistics authority instead of PAs and a greater - even though partial - financial autonomy in order to facilitate the investments. Waiting for the structural changes, the increase of the power of the port president, the modernization of the administrative procedures and the increase of the concession flexibility are effective tools to positively impact on the Italian ports system.

\section{References}

AGCM - Autorità Garante Concorrenza e Mercato (1997). Indagine conoscitiva nel settore dei servizi portuali, Rome.

AGCM - Autorità Garante Concorrenza e Mercato (2014). As1027 - Tariffe per il servizio di pilotaggio nei porti nazionali, Rome.

Assoporti - Italian Association of Seaports (2014). www.assoporti.it

Baird, A.J. (2000). Port privatisation: objectives, extent, process, and the UK experience, International Journal of Maritime Economics, 2(3), pp. 177-194.

Bergantino, A.S. (2002). The European commission approach to port policy: some open issues, International Journal of Transport Economics, 29, pp. 337-379.

Bottasso, A., Conti, M., Ferrari, C., and Tei, A. (2014). Ports and Regional development: A spatial analysis on a panel of European regions. Transportation Research Part A, 65, pp. 44-55.

Bottasso, A., Conti, M., Ferrari, C., Tei., A. (2013). Alcune riflessioni sulla pratica regolatoria, con riferimento ad alcuni settori dell'industria dei trasporti, Rivista di Economia e Politica dei Trasporti, 3, pp. 1-13.

Brignardello, M. (2010). Le concessioni di aree e di banchine portuali ex art. 18 1. N. 84/1994: problemi interpretativi e prospettive di riforma, Diritto della Navigazione, 2, pp. 467-498.

Carbone, S.M. and Munari, F. (2006). La disciplina dei porti tra diritto comunitario e diritto interno, Giuffré Ed., Milan.

Carbone, S.M. and Munari F. (2010). La disciplina dei porti tra diritto comunitario e diritto interno, Diritto Marittimo, pp. 765 ss.

Cariou, P., Dagnet, F. and Fedi, L. (2014) The new governance structure of French seaports. Maritime Policy and Management, 41, 5, pp. 430-443. 
Cesaroni, G. and De Stefanis, F. (2014). L'efficienza delle Autorità Portuali nell'impiego dei mutui per la realizzazione di infrastrutture, Rivisita di Economia e Politica dei Trasporti, 1, pp. 2-23.

Confetra (2011), La Logistica Italiana, Rapporto della 66 Assemblea Annuale, Roma.

Consulta Generale per l'Autotrasporto e la Logistica (2011), Il Piano Nazionale della Logistica, www.mit.gov.

Costa, P. and Casagrande M. (2011). Dalla concorrenza nei porti alla concorrenza tra i porti. Il Caso dei Servizi Tecnico-Nautici in Italia, Marsilio, Italy.

De Langen P.W. and Heij, C. (2014), Corporatisation and Performance: A Literature Review and an Analysis of the Performance Effects of the Corporatisation of Port of Rotterdam Authority, Transport Reviews, pp. 1-19.

European Commission (2004). Directive n. 2004/17/EC, Brussels.

European Commission (2013). Proposal for a regulation to the market access to port services and financial transparency of ports. COM(2013/296), Bruxelles.

European Commission (2014). Directive 2014/25/UE, Brussels.

Ferrari C., Parola F., Tei A. (2013). Slow Steaming and Shipping Performances: How a Slowing Down Strategy Can Speed Up the Shipping Market Performances. In: Proceedings of the World Conference on Transport Research 2013.

Ferrari, C., and Musso, E. (2011). Italian ports: towards a new governance?, Maritime Policy \& Management, 38(3), pp. 335-346.

Ferrari, C., Parola, F., and Benacchio, M. (2008). Network economies in liner shipping: the role of home markets, Maritime Policy \& Management, 35, n. 2, pp. 127-143

Ferrari, C., Parola, F., and Gattorna, E. (2011), Measuring the quality of port hinterland accessibility: the Ligurian case, Transport Policy, 18, 2, pp. 382-391.

Ferrari, C., Puliafito, P.P. and Tei, A. (2013). Performance and quality indexes in the evaluation of the terminal activity: A dynamic approach, Research In Transportation Business \& Management, 8, pp. $77-86$.

ITMMA - Institute of Transport and Maritime Management Antwerp (2008) 'The awarding of seaport terminals in Europe: Results from ITMMA survey commissioned by ESPO', Antwerp.

Kaselimi, E., Notteboom, T. and De Borger, B. (2011). A game theoretical approach to competition between multi-user terminals: the impact of dedicated terminals, Maritime Policy and Management, 38(4), pp. 395-414.

Meersman H., Van de Voorde, E. and Vanelslander, T. (2009) Future Challenges for Port and Shipping Sector, Informa, London.

Ministry of Transport - Ministero delle Infrastrutture e dei Trasporti. (2014), Relazione sull'attivita` delle Autorita`Portuali, years 1995-2012, Roma. 
Notteboom, T. and Verhoeven, P. (2009). The awarding of seaport terminals to private operators: current practices and viewpoints in European ports, Proceedings of IAME 2009 Conference, Copenhagen.

Notteboom, T., and Rodrigue, J. P. (2005). Port regionalization: Towards a new phase in port development. Maritime Policy and Management, 32, 3, 297-313

Pallis, A., Notteboom, T., and de Langen, P.W. (2008). Concession agreements, capabilities and market entry, Maritime Economics and Logistics, 10, pp. 209 - 228.

Paris MoU (2014). Port State Control Consolidating Progress. Annual Report 2013, www.parismou.org

Parola, F., Tei, A. and Ferrari, C. (2012). Managing port concessions: evidence from Italy', Maritime Policy And Management, 39 (1), pp. 45-61.

Righetti, G. (1987). Trattato di Diritto Marittimo, Giuffré Ed., Milan.

Theys, C. and Notteboom, T. (2010). The economics behind the awarding of terminals in seaports, Research in Transportation Economics, 27, pp. 37-50.

Torbianelli, V. (2013). Quanto, dove costano i porti ai contribuenti? Approfondimenti per una geografia critica dell'autonomia finanziaria nel settore portuale italiano, Rivista di Economia e Politica dei Trasporti, 2, pp. 2-15.

Van der Host M.R., and De Langen, P.W. (2008). Coordination in hinterland transport chains: a major challenge for the seaport community, Maritime Economics \& Logistics, 10, pp. 108-129.

Wang G., Notteboom, T., and Pallis, A. (2014). Incentives in Cruise Terminal Concession Contracts, Proceedings of 2014 IAME Conference, Norfolk.

World Bank. (2001). World Bank Port Reform Tool kit, Transport Division, Washington DC. 
